\title{
EVALUATION OF SUITABILITY OF HAZELNUT SHELL ENERGY FOR PRODUCTION OF BIOFUELS
}

\author{
Tomasz Hebda, Beata Brzychczyk, Slawomir Francik, Norbert Pedryc \\ University of Agriculture in Krakow, Poland \\ tomasz.hebda@ur.krakow.pl, beata.brzychczyk@ur.krakow.pl, \\ slawomir.francik@urk.edu.pl,norbert.pedryc@ur.krakow.pl
}

\begin{abstract}
One of the many advantages in favor of the energy use of biomass is the reduction of greenhouse gas emissions, e.g. carbon dioxide and toxic exhaust components. Depending on the physicochemical and thermal properties, and especially on the calorific value, biomass can be used in heating and electricity. Biomass can be any organic material containing carbon, but without significant physico-chemical changes, which would lead to the formation of specific properties of crude oil or hard coal. The aim of this work was to determine selected properties of hazelnut shells in terms of their suitability for biofuel production. The hazelnut shells of the following varieties were analyzed: Casina, Catalan, Webba Cenny, Berger, Trapezian and Barcelonski. The examined hazelnuts were characterized by slight physicochemical differentiation. The criteria for biomass energy assessment were: calorific value, moisture content, heat of combustion, flash point, volatile content and bulk density. Measurements of selected parameters were made using standardized measuring devices. Among the tested varieties of hazelnut shells, the highest caloric value was characterized by the Casina variety $(18.42$ $\left.\mathrm{MJ} \mathrm{kg}^{-1}\right)$, and the smallest for the Trapezian variety $\left(17.21 \mathrm{MJ}^{-1}\right)$. The highest content of ash was observed for the Catalan variety $(1.4 \%)$ and the lowest for Casina $(0.89 \%)$. The highest content of volatile parts was noted for Trapezuński $(72.3 \%)$ and the smallest for Berger variety $(71.73 \%)$. The highest temperature of ignition was distinguished for the variety Webba Cenny $\left(425.07^{\circ} \mathrm{C}\right)$, and the lowest for the variety Trapezian $\left(368.4^{\circ} \mathrm{C}\right)$. The moisture content of the tested walnut shells ranged from 5.8 to $6.8 \%$. The conducted research and the analysis of selected physicochemical properties show that hazelnut shells are suitable for the production of biofuels.
\end{abstract}

Keywords: biomass, biofuels, shells, physicochemical properties.

\section{Introduction}

Currently, despite energy being obtained mainly from non-renewable sources, it is being looked for appropriate substitutes in unconventional energy. Negative estimates of the rate of consumption of fuels from oil or coal contributed to such activities.

In the strategy for the development of renewable sources, the dominant role was assigned to biomass. It may be the starting material for the production of solid, liquid and gaseous biofuels, using various processes, such as gasification or fermentation $[1 ; 2]$. Processed biomass is characterized not only by a lower bulk density, but also by better energy properties, for example a higher calorific value [3]. One of the many advantages in favor of the energy use of biomass is the reduction of greenhouse gas emissions, carbon dioxide and toxic exhaust components - $\mathrm{SO}_{2}, \mathrm{NOx}$ and $\mathrm{CO}$ [4-5].

Shells of nuts such as almonds, walnuts, cashews and hazelnuts are wood waste that can be used to produce energy. In the literature on the subject, one can find publications on the possibilities of using palm kernel shells, walnut shells, cashew shells and macadamia nut shells [6-12]. However, despite their huge potential as a source of energy, their thermal properties are still little known.

The aim of the work was to determine selected properties of hazelnut shells in terms of their suitability for energy use - for the production of biofuels. The hazelnut shells of six varieties were analyzed. The scope of work included the determination of: specific heat, calorific value, ash content, ignition temperature, humidity and bulk density. The following varieties were used for the research: Trapezian, Berger, Barcelonski, Weba Cenny, Catalan and Casina.

\section{Materials and methods}

Before commencing the specific tests, the material was ground in a cryogenic mill Spex Sample Prep type 6770 freezer / Mill. The tests were carried out in accordance with the following standards:

- PN-EN ISO 18134-3: 2015-11 - Solid biofuels - Determination of moisture content - Drying method - Part 3: Moisture in the overall analytical sample [13]

- PN-EN 14775 - Solid biofuels - Determination of ash content [14]

- PN-EN 15148-2010 Solid biofuels - Determination of volatile matter content [15]

- PN-EN 14918-2011 Solid biofuels - Determination of calorific value [16] 
- PN-ISO 1928: 2002 - Solid fuels - Determination of combustion heat in a calorimetric bomb and calculation of calorific value [17]

The following devices were used in the tests:

- Pol-Eko type SLW 53 TOP convection dryer,

- muffle furnace SNOL 6,7 / 1300 LSM01,

- Ika Calorimeters C6000 calorimeter,

- Radwag WPE 510 / C / 2 laboratory scale.

\section{Results and discussion}

The graph (Fig. 1) shows the moisture content in shells of individual hazelnut varieties. The analysis showed that the Kataloński variety had the lowest moisture content (only $5.78 \%$ ). Only $0.1 \%$ higher moisture content was shown by Barcelonski nut shells. The Webba Cenny and Casina varieties had very similar shell moisture, the difference between them is only $0.11 \%$. Whereas the Bergera and Trapezuński variety have the highest moisture content, which is on average 6.50- 6.79\%.

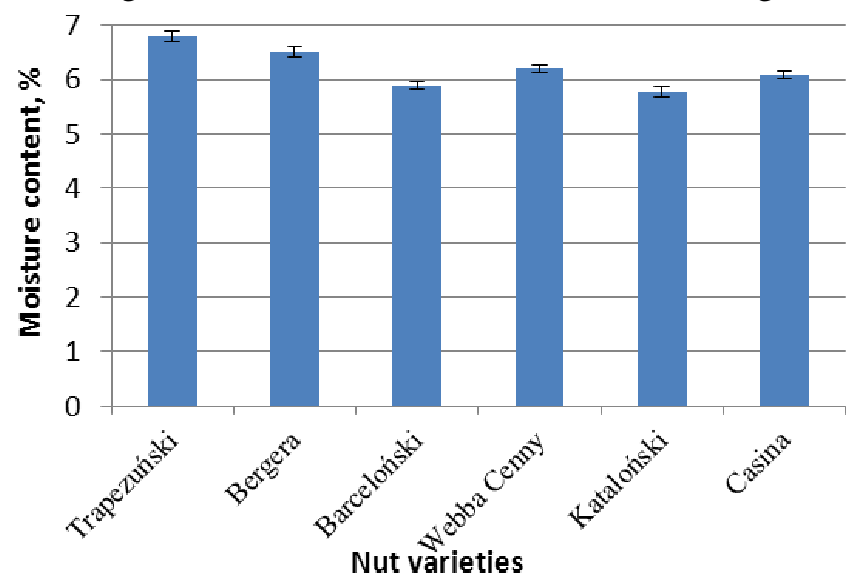

Fig. 1. Moisture content in hazelnut cover

The next stage of the research included determining the bulk density. The presented analysis shows that the highest density was exhibited by Webba Cenny $\left(425.07 \mathrm{~kg} \cdot \mathrm{m}^{-3}\right)$, while the smallest by Trapezuński and Barceloński varieties (respectively: $368.44 \mathrm{~kg} \cdot \mathrm{m}^{-3}$ and $376.96 \mathrm{~kg} \cdot \mathrm{m}^{-3}$ ). For the remaining varieties, the crust density was similar (Fig. 2).

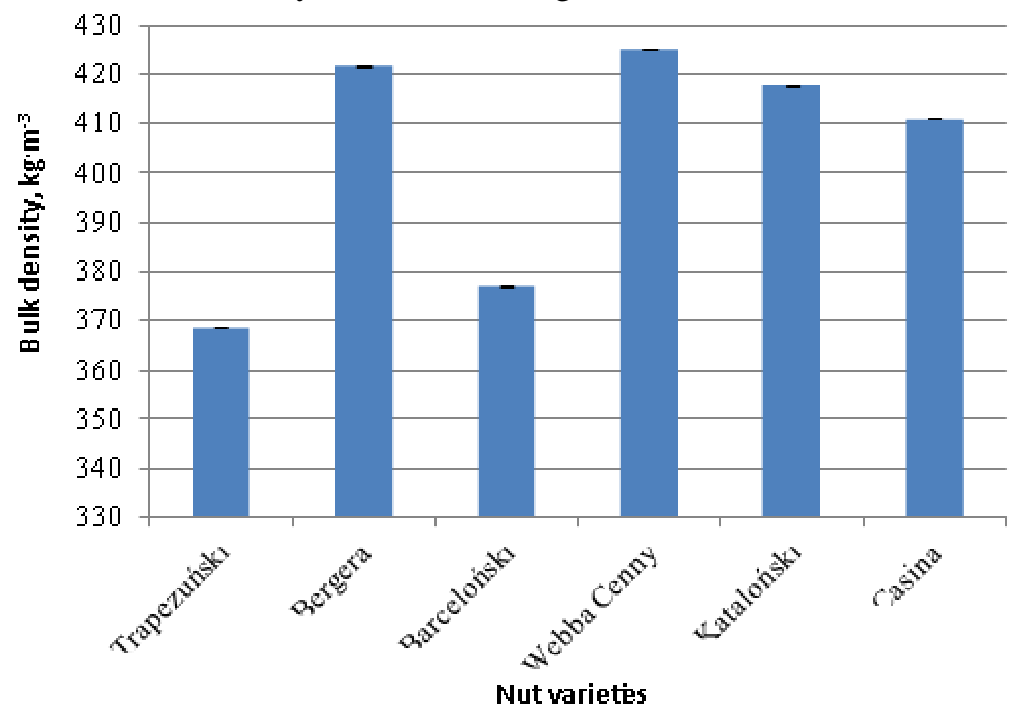

Fig. 2. Bulk density of nut shells

The graph (Fig. 3) shows the results of the analysis of the heat of combustion. We can conclude that the highest value of heat of combustion, among all the analyzed varieties, was observed for Trapezuński nut shells (more than $20 \mathrm{MJ} \cdot \mathrm{kg}^{-1}$ ), while the lowest for Casina variety shell $\left(19.49 \mathrm{MJ} \cdot \mathrm{kg}^{-}\right.$ 
$\left.{ }^{1}\right)$. The value of heat of combustion of Bergera, Berceloński and Webba Cenny and Kataloński shells is similar to each other and amounts to $20 \mathrm{MJ} \cdot \mathrm{kg}^{-1}$ and $19.7 \mathrm{MJ} \cdot \mathrm{kg}^{-1}$ in succession.

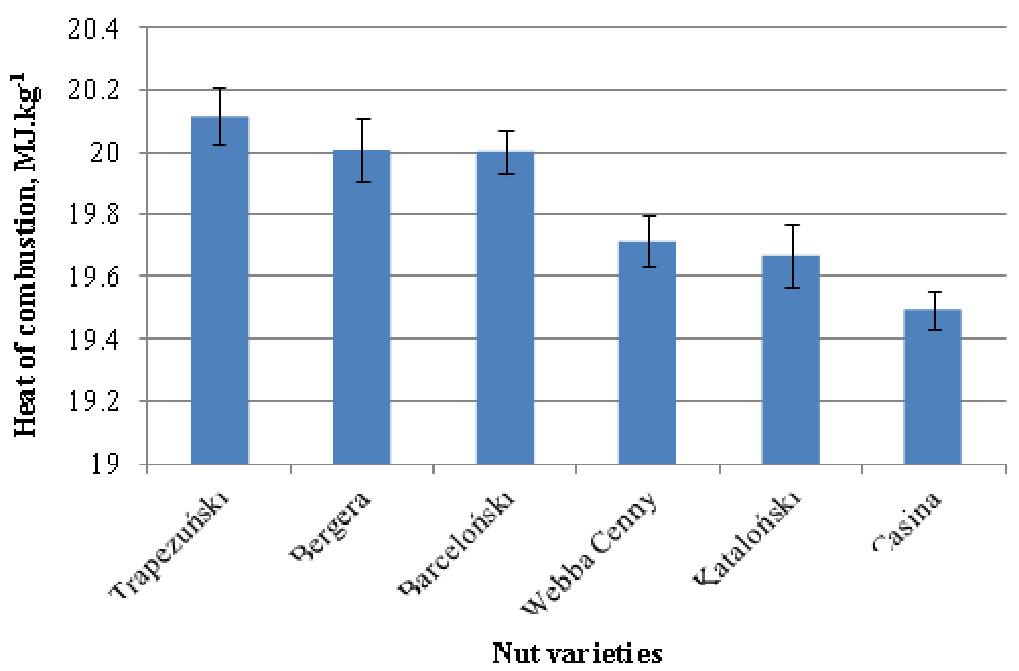

Fig. 3. Heat of burning nut shell

Subsequent research concerned determination of the calorific value of shells of individual hazelnut varieties. The test results are shown in the graph (Fig. 4). The highest calorific value is observed for the variety Casina $\left(18.42 \mathrm{MJ} \cdot \mathrm{kg}^{-1}\right)$, and the variety Barceloński $\left(18.22 \mathrm{MJ} \cdot \mathrm{kg}^{-1}\right)$. The lowest calorific value was measured for the shells of the Trapezuński variety, only $17.21 \mathrm{MJ} \cdot \mathrm{kg}^{-1}$. The Bergera and Kataloński nuts had a similar calorific value of the shell, which was on average 17.5 $\mathrm{MJ} \cdot \mathrm{kg}^{-1}$.

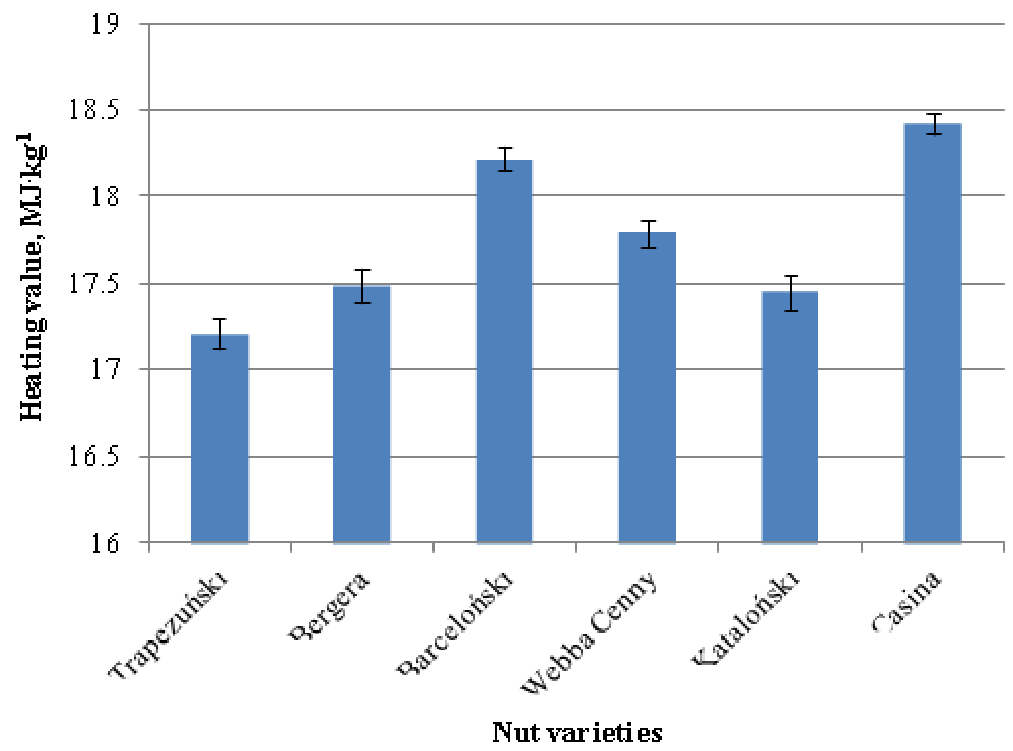

Fig. 4. Calorific value of nut shells

The graph (Fig. 5) shows the results of the ignition temperature measurement. The value of this temperature, for all the analyzed varieties, ranged from $249{ }^{\circ} \mathrm{C}$ (for the nut shell varieties of Trapezuński and Webba Cenny) to over $253{ }^{\circ} \mathrm{C}$ for the Barceloński variety.

The next chart illustrates the results of the ash content measurement (Fig. 6). The highest ash content was determined, after burning, for the Kataloński (1.4\%) and Webba Cenny walnut shells $(1.22 \%)$, while the lowest for the Casina and Bergera variety ( $0.89 \%$ and $0.98 \%$, respectively). The values of the tested parameters are slightly different for individual varieties.

The last stage of the study involved the measurement of volatile parts (Fig. 7). Differences in the obtained results are very small and do not appear to be statistically significant. The lowest value of 
volatile parts was observed for the-Bergera nut shells (almost $71.8 \%$ ). Only $0.5 \%$ more volatile parts were found in the Trapezuński variety (the most in the whole experiment).

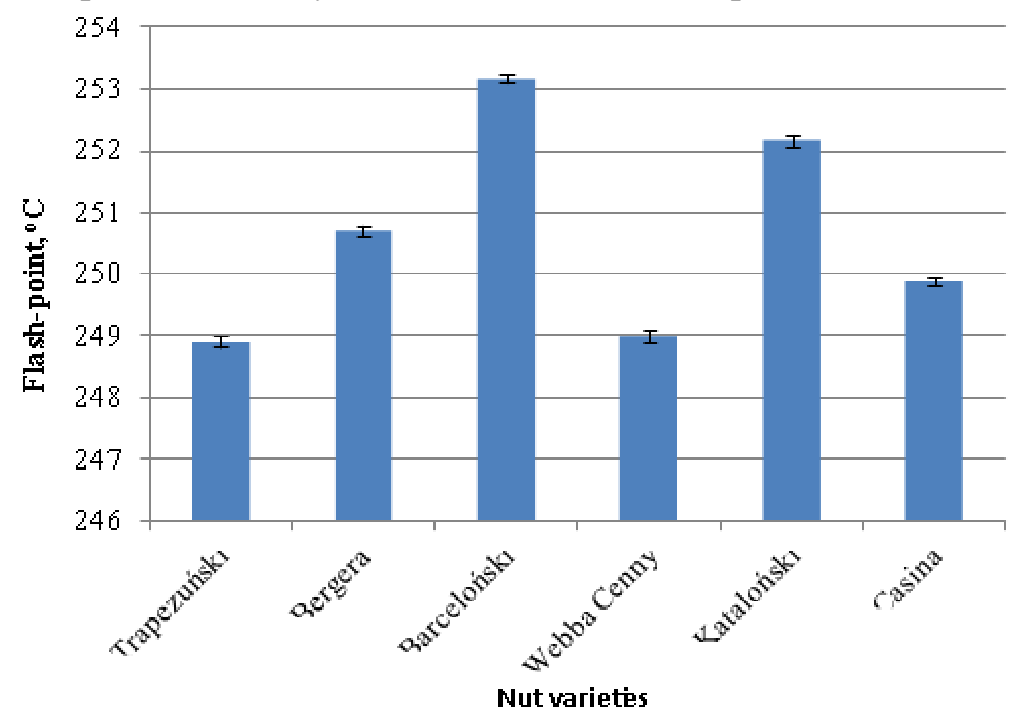

Fig. 5. Ignition temperature of hazelnut shells

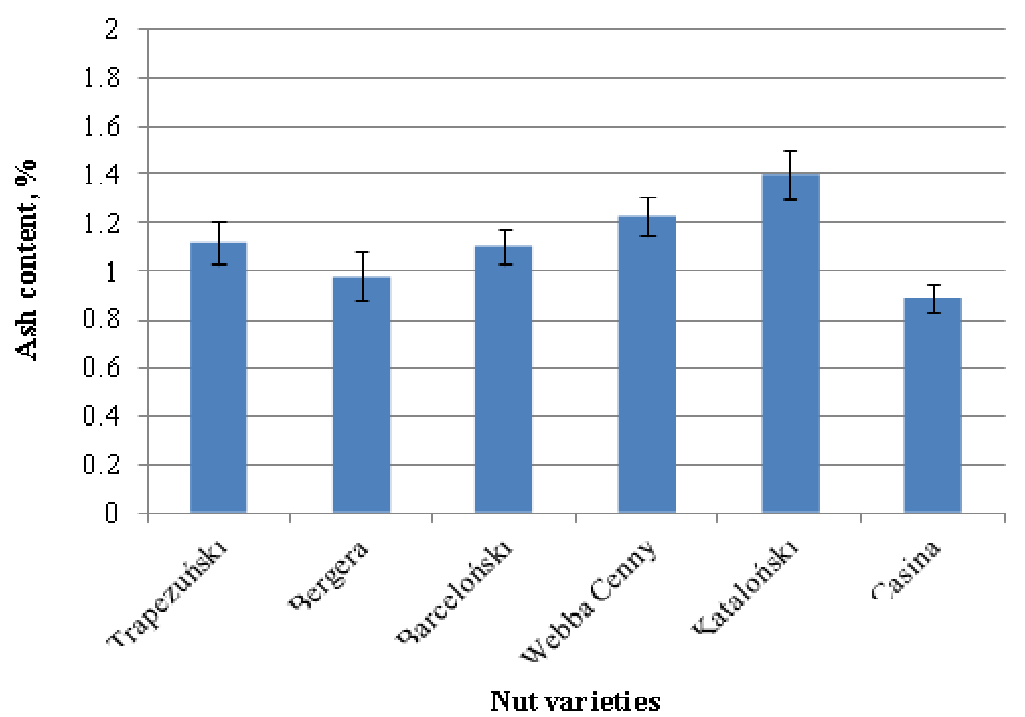

Fig. 6. Content of ash in nut shell

The statistical analysis of the results included conducting the multifactor analysis of variance for individual data obtained during the tests. The independent variables were: moisture content, volatile parts, ash content, heat of combustion, calorific value and flash point. The results of the analysis of variance are presented in Table 1. The test showed a significant effect of almost all factors on the usefulness of hazelnut shells for the production of biofuels.

The next stage of the work consisted of carrying out the Duncan test (Table 2). Its results showed, for the factor calorific value, the existence of one homogeneous group including the following varieties: Kataloński and Bergera. There were no significant differences in the calorific value in this group. For the heat of combustion factor, two homogeneous groups were observed for the following varieties: Trapezuński, Bergera, Webb Cenny, Kataloński and Barceloński. The second group includes Casina, Kataloński and Webba Cenny. It was found that 3 out of 6 varieties can belong to two homogeneous groups, which shows that there are no statistical differences between them in the tested factor. One homogeneous group was also distinguished for the ash content factor. It consists of Trapezuński, Bergera, Webba Cenny and Barceloński. In the case of volatile parts, homogeneous groups were not observed, which indicates statistically significant differences between the varieties. Also in the case of flashpoints, variants with statistically insignificant differences form one homogeneous group. These include Trapezuński, Berger, Webb Cenny and Casina. 


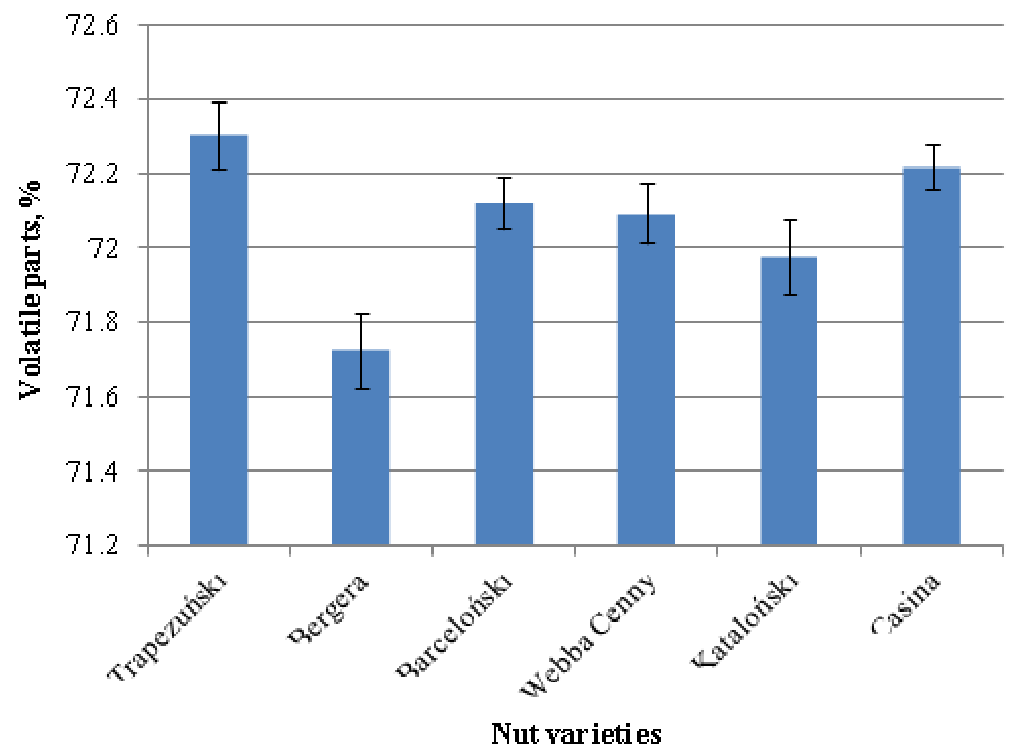

Fig. 7. Volatile parts of nut shells

Table 1

One-dimensional significance tests for obtained test results

\begin{tabular}{|c|c|c|c|c|}
\hline Variable & $\begin{array}{c}\text { Average } \\
\text { square effect }\end{array}$ & $\begin{array}{c}\text { Mean } \\
\text { squared error }\end{array}$ & $\boldsymbol{F}$ & The $\boldsymbol{p}$-value \\
\hline Moisture content & 0.003 & 0.0017 & 1.90195 & 0.080334 \\
\hline Calorific value & 0.432 & 0.0469 & 9.19400 & 0.000000 \\
\hline Heat of combustion & 0.000 & 0.0000 & 3.51524 & 0.000022 \\
\hline Ash content & 0.002 & 0.0002 & 11.43529 & 0.012798 \\
\hline Volatile parts & 0.000 & 0.0001 & 6.49524 & 0.000003 \\
\hline Flash point & 4379.615 & 110.7726 & 39.53701 & 0.000000 \\
\hline
\end{tabular}

Duncan's test results for main factors

\begin{tabular}{|c|c|c|c|c|c|}
\hline Odmiana & $\begin{array}{c}\text { Calorific } \\
\text { value }\end{array}$ & $\begin{array}{c}\text { Heat of } \\
\text { combustion }\end{array}$ & $\begin{array}{c}\text { Ash } \\
\text { content }\end{array}$ & $\begin{array}{c}\text { Volatile } \\
\text { parts }\end{array}$ & Flash point \\
\hline Trapezuński & A & A & A & A & A \\
\hline Bergera & B & A & A & B & A \\
\hline Barceloński & C & A & A & C & B \\
\hline Webba Cenny & D & A B & A & D & A \\
\hline Kataloński & B & A B & B & E & B \\
\hline Casina & E & B & C & F & A \\
\hline
\end{tabular}

Comparing the data contained in the literature $[5 ; 18 ; 19]$ with the analysis of the tested raw material, it can be clearly stated that hazelnut shells of the six presented varieties are suitable for the production of biofuels. In terms of physicochemical properties, these data are very similar to the energy plants used in Poland and are already used to produce biofuels.

\section{Conclusions}

The conducted research and analysis of selected physicochemical properties show that hazelnut shells are suitable as a raw material for the production of biofuels.

1. Among the tested varieties of hazelnut shells the highest calorific value was observed for Casina (almost $18.5 \mathrm{MJ} \cdot \mathrm{kg}^{-1}$ ), and the smallest for the Trapezian variety (over $17 \mathrm{MJ} \cdot \mathrm{kg}^{-1}$ ).

2. The highest ash content was found in the Catalan variety $(1.4 \%)$ and the lowest in Casina $(0.89 \%)$. 
3. The highest content of volatile parts was observed for the Trapezian variety (72.3\%), and the smallest for the Berger variety $(71.73 \%)$.

4. The heat of burning the shells of the tested nut varieties ranged from 19.5 to $20.1 \mathrm{MJ} \cdot \mathrm{kg}^{-1}$ and was comparable with many sources of biomass of agricultural origin.

\section{Acknowledgements}

This research was financed by the Ministry of Science and Higher Education of the Republic of Poland.

\section{References}

[1] Lewandowski W.M, Ryms M.: Biofuels. Ecological renewable energy sources, WNT, Warsaw, 2013.

[2] Havrland B., Ivanova T., Łapczyńska-Kordon B., Kolarikova M. Comparative analysis of bio-raw materials and biofuels. 12th International Scientific Conference on Engineering for Rural Development - Proceedings, Latvia University of Agriculture Faculty of Engineering 2013, T. 12, pp. 541-544.

[3] Jewiarz M., Frączek J., Mudryk K., Wróbel M., Dziedzic K. Analysis of MSW Potential in Terms of Processing into Granulated Fuels for Power Generation. Mudryk, Krzysztof, Werle, Sebastian (Eds.). Renewable Energy Sources: Engineering, Technology, Innovation - ICORES 2017. Springer 2018.

[4] Basu P. Biomass gasification and pyrolysis-practical design and theory. Oxford: Elsevier; 2010. pp. 27-55.

[5] Ayúe Özyuguran, Serdar Yaman. Prediction of Calorific Value of Biomass from Proximate Analysis. Energy Procedia 107, 2017, pp. 130-136.

[6] Tsamba A.J., Yang W., Blasiak W., Pyrolysis characteristics and global kinetics of coconut and cashew nut shells. Fuel Processing Technology, Volume 87, Issue 6, June 2006, pp. 523-530

[7] Imtiaz Ali, Haitham Bahaitham, Raed Naebulharam. A comprehensive kinetics study of coconut shell waste pyrolysis. Bioresource Technology. Volume 235, July 2017, pp. 1-11

[8] Demirbas A, Effect of temperature on pyrolysis products from four nut shells. Journal of Analytical and Applied Pyrolysis. Volume 76, Issues 1-2, 2006, pp. 285-289

[9] Licursi D, Antonetti C, Fulignati S., Vitolo S, Puccini M., Ribechini E., Bernazzani L., Raspolli Galletti A.M. In-depth characterization of valuable char obtained from hydrothermal conversion of hazelnut shells to levulinic acid. Bioresource Technology 244, 2017, pp. 880-888.

[10]Demirbaş A. Fuel Characteristics of Olive Husk and Walnut, Hazelnut, Sunflower, and Almond Shells, Energy Sources, 24:3, 2010, 215-221, DOI: 10.1080/009083102317243601.

[11] Naphat A. Heating Energy Briquettes from Cashew Nut Shell. 2015. DOI: 10.13140/RG.2.1.1514.4165.

[12] Bada S.O., Falcon R.M.S., Falcon L.M., Makhula M.J.. Thermogravimetric investigation of macadamia nut shell, coal, and anthracite in different combustion atmospheres. The Journal of The Southern African Institute of Mining and Metallurgy, V. 115, 2015, pp. 741-746

[13]PN-EN ISO 18134-3:2015-11 - Solid biofuels - Determination of moisture content - Drying method - Part 3: Moisture in the overall analytical sample

[14] PN - EN 14775 - Solid biofuels - Determination of ash content

[15] PN - EN 15148-2010 Solid biofuels - Determination of volatile matter content

[16]PN - EN 14918-2011 Solid biofuels - Determination of calorific value

[17] PN-ISO 1928:2002 - Solid fuels - Determination of combustion heat in a calorimetric bomb and calculation of calorific value

[18] Wróbel M., Mudryk K., Jewiarz M., Głowacki S., Tulej W. (2018) Characterization of Selected Plant Species in Terms of Energetic Use. In: Mudryk K., Werle S. (eds) Renewable Energy Sources: Engineering, Technology, Innovation. Springer Proceedings in Energy. Springer, Cham pp. 671-681 doi.org/10.1007/978-3-319-72371-6_66

[19] Niemczyk M., Kaliszewski A., Jewiarz M., Wróbel M., Mudryk K., 2018 Productivity and biomass characteristics of selected poplar (Populus spp.) cultivars under the climatic conditions of northern Poland Biomass and Bioenergy,Vol. 111, pp. 46-51, ISSN 0961-9534, doi.org/10.1016/j.biombioe.2018.02.002. 